Innowacje w Pielęgniarstwie i Naukach o Zdrowiu

$2(1) / 2016$

ISSN: 2451-1846

DOI: http://dx.doi.org/10.21784/IwP.2016.009

Łukasz Majerski ${ }^{1}$

${ }^{1}$ Samodzielny Publiczny Zespół Zakładów Opieki Zdrowotnej w Sierpcu

\title{
Satysfakcja pacjentów z opieki pielęgniar- skiej realizowanej w Izbie Przyjęć
}

\section{Patient satisfaction with nursing care implemented in the Emer- gency Room}

\section{Streszczenie}

Wstęp. Jakość świadczonych usług udzielanych w zakładach opieki zdrowotnej jest jednym z najważniejszych wyzwań współczesnej ochrony zdrowia. Satysfakcja z opieki pielęgniarskiej jest kluczowym zagadnieniem, które powinno być monitorowane w sposób ciągły przy użyciu odpowiednich narzędzi. Satysfakcja jest odpowiedzią pacjenta na proces opieki zdrowotnej. Niewątpliwie staje się ona istotnym kryterium oceny jakości opieki medycznej i oznacza stopień, w jakim opieka przez chorego jest akceptowalna w odniesieniu do jego potrzeb i oczekiwań. Systematyczne dokonywanie oceny opieki pielęgniarskiej staje się bodźcem do ciągłego doskonalenia i podnoszenia na wyższy poziom systemu ochrony zdrowia.

Cel. Celem niniejszej pracy jest ocena i analiza satysfakcji pacjentów z poziomu i jakości opieki pielęgniarskiej realizowanej w Izbie Przyjęć.

Materiał i metody. Badania zostały przeprowadzone w Izbie Przyjęć Samodzielnego Publicznego Zespołu Zakładów Opieki Zdrowotnej w Sierpcu w okresie od maja do listopada 2015 roku w grupie 112 pacjentów. Badania 
wykonano metodą sondażu diagnostycznego z użyciem kwestionariusza ankiety własnej konstrukcji.

Wyniki. W badanej grupie znajdowały się osoby w wieku od 21 roku życia do 80 lat, gdzie większość stanowiły kobiety. Wykształcenie osób badanych to głównie średnie i wyższe a miejscem zamieszkania dla większości badanych było miasto. Osoby badane przyjmowane były do szpitala głównie w trybie planowym. Wyniki badań poddane zostały analizie statystycznej, a następnie opracowane i przedstawione w sposób graficzny i opisowy.

Wnioski. 1. Pacjenci w zdecydowanej większości ocenili opiekę pielęgniarską realizowaną w Izbie Przyjęć na poziomie dobrym i bardzo dobrym. 2. Na ocenę poziomu opieki pielęgniarskiej w Izbie Przyjęć ma wpływ posiadane wykształcenie ankietowanych. Natomiast płeć, wiek, stan cywilny, miejsce zamieszkania oraz tryb zgłoszenia się pacjenta do szpitala nie mają wpływu. 3. Na ocenę jakości opieki pielęgniarskiej w Izbie Przyjęć nie ma wpływu płeć, wiek, stan cywilny, miejsce zamieszkania, wykształcenie oraz tryb zgłoszenia się pacjenta do szpitala.

\begin{abstract}
Introduction. The quality of services provided in health care units is one of the most important challenges of modern health protection. Satisfaction with nursing care is a key issue that should be monitored continuously using appropriate tools. Satisfaction is the response of the patient to the healthcare process. Undoubtedly, it becomes an important criterion for assessing the quality of care and is the degree to which the care is acceptable for the patient in relation to their needs and expectations. Regular assessments of nursing care becomes an incentive for continuous improvement and raising the health system to a higher level.
\end{abstract}

Aim. The aim of this study is to assess and analyze patiens't satisfaction with the level and quality of nursing care implemented in the Emergency Room.

Material and Methods. The study was conducted in the Emergency Room of the Independent Public Complex of Health Care in Sierpc in the period from May to November 2015 in a group of 112 patients. The study was performed using diagnostic survey and applying a questionnaire of our own design.

Results. The study group included respondents aged from 21 to 80 years, where the majority were women. The respondents had mainly secondary and higher education and the place of residence for the majority of the respondents was town. The surveyed were admitted to hospital mainly elec- 
tive. The test results were subjected to statistical analysis and then developed and presented in a graphic and descriptive form.

Conclusions. 1. Patients in the vast majority evaluated nursing care implemented in the Emergency Room as good and very good. 2. The assessment of the level of nursing care in the Emergency Room is affected by the level of respondents' education. Whereas gender, age, marital status, place of residence and the mode for patient's application to hospital do not have any impact. 3. The assessment of the quality of nursing care in the Emergency Room is not affected by gender, age, marital status, place of residence, education and mode of application of the patient to the hospital.

Słowa kluczowe: satysfakcja pacjentów, opieka pielęgniarska

Key words: satisfaction of patients, nursing care

\section{Wstęp}

Satysfakcja określana jest ogólnie jako poczucie zadowolenia i przyjemności, których doznajemy gdy osiągamy coś na czym nam istotnie zależało. Stan satysfakcji jest odczuciem subiektywnym i powiązanym z osobistym poczuciem spełnienia i doświadczeniami.

Satysfakcja jest zjawiskiem psychologicznym, które zmienia się wraz z szybkością reakcji na sytuacje stresowe budzące negatywne emocje. Oznacza to, że kluczową rolę w odczuwaniu satysfakcji mają czynniki zewnętrzne i wewnętrzne. Satysfakcja jest niewątpliwie jedną z metod oceny jakości opieki medycznej świadczonej w placówkach służby zdrowia. W 1975 roku Risser N. opracował Skalę Zadowolenia, gdzie zdefiniował satysfakcję jako „stopień zgodności między oczekiwaniami pacjenta co do idealnej opieki pielęgniarskiej, a percepcją opieki, którą realnie on otrzymuje". Tak sformułowana definicja jest najczęściej stosowana dla celów praktyki pielęgniarskiej. Ponadto uzupełnieniem powyższej terminologii są słowa Kotlera P., który stwierdza, że „satysfakcja jest stopniem, w jakim wykonana usługa odpowiada oczekiwaniom nabywcy" $[1,2]$. 
Stopień satysfakcji pacjenta ze świadczonych usług medycznych jest jednym z kryterium oceny jakości opieki pielęgniarskiej. Pacjenci zgodnie podkreślają, że najważniejszymi cechami, którymi powinien odznaczać się personel pielęgniarski to przede wszystkim: profesjonalizm, wysokie kwalifikacje, fachowa pomoc, łagodzenie uciążliwych objawów, zapewnienie intymności, stworzenie higienicznych i bezpiecznych warunków oraz rzetelnej i kulturalnej informacji o stanie zdrowia i świadczonych usługach. Należy szczególnie podkreślić, że określone czynniki socjodemograficzne, umiejętność kultury wypowiedzi, środowisko zewnętrzne, relacje pacjent-pielęgniarka i kompetentne wykonywanie zadań mają ogromny wpływ na satysfakcję pacjentów z opieki pielęgniarskiej [3].

Satysfakcja pacjenta wpływa na jakość usług medycznych, którą Światowa Organizacja Zdrowia określa jako „rezultat, sposób użycia środków, organizację usług oraz satysfakcję pacjenta”. Wyróżniamy kilka kryteriów, które stanowią istotę jakości i zaliczamy do nich między innymi: zależność między sukcesem organizacji a jakością, wyeliminowanie marnotrawstwa, korygowanie i naprawianie błędów, doskonalenie efektywności gospodarowania, obniżanie kosztów działalności bez ujemnych skutków dla pacjenta. Poprawa jakości uzależniona jest również od usług, materiałów, sprzętu, aparatury i wykwalifikowanej kadry. Kryteria określające jakość usług medycznych mają kolosalny wpływ na całkowitą ocenę satysfakcji pacjenta. Kryteriami tymi są: dostępność, uprzejmość, rzetelność, bezpieczeństwo i zaufanie, czas, jakość kliniczna usług medycznych, rzetelność świadczonych usług, zasadność i odpowiedzialność realizowanych świadczeń medycznych [4].

Celem badań własnych jest ocena i analiza satysfakcji pacjentów z poziomu i jakości opieki pielęgniarskiej realizowanej w Izbie Przyjęć. 


\section{Materiał i metody}

Badania zostały przeprowadzone w Izbie Przyjęć Samodzielnego Publicznego Zespołu Zakładów Opieki Zdrowotnej w Sierpcu w okresie od maja do listopada 2015 roku. Grupą badaną było 112 pacjentów w wieku od 21 roku życia do 80 lat. Kobiety stanowiły 50,9\% osób badanych, a mężczyźni 49,1\%. Miejscem zamieszkania dla większości badanych była wieś - 65,2\%. Pod względem stanu cywilnego były to głównie osoby pozostające w związku - 64,3\%. W zakresie wykształcenia dominowało wykształcenie średnie lub wyższe 67,0\%. Tryb przyjęcia do szpitala osób badanych dla większości był trybem planowanym - 61,6\%.

Metodą badań był sondaż diagnostyczny, a technikę stanowiło ankietowanie $\mathrm{z}$ wykorzystaniem kwestionariusza ankiety własnej konstrukcji. Na przeprowadzenie badań uzyskano zgodę Komisji Bioetycznej Uniwersytetu Mikołaja Kopernika w Toruniu przy Collegium Medicum w Bydgoszczy - Nr KB 416/2015. Wyniki badań poddane zostały analizie statystycznej z wykorzystaniem testu chi - kwadrat i współczynnika korelacji C Pearsona. Dla wszystkich analiz przyjęto współczynnik istotności na poziomie 0,05.

\section{Wyniki}

\section{Satysfakcja pacjentów z opieki pielęgniarskiej w Izbie Przyjęć według analizy ogólnej}

Uzyskane wyniki ocen według opinii pacjentów na temat opieki pielęgniarskiej świadczonej w Izbie Przyjęć przedstawiono w tabeli 1. W ocenie tej przyjęto skalę od 2 do 5 , gdzie poziom 2 oznaczał ocenę negatywną, poziom 3 oznaczał ocenę dostateczną, poziom 4 to ocena dobra, a poziom 5 stanowił ocenę bardzo dobrą.

Tabela 1. Ocena satysfakcji pacjentów z opieki pielęgniarskiej w Izbie Przyjęć

\begin{tabular}{|l|c|c|c|}
\hline \multicolumn{2}{|c|}{ Kategorie opinii pacjentów } & $\begin{array}{c}\text { Średnia } \\
\text { ocen } \\
(\mathrm{x})\end{array}$ & $\begin{array}{c}\text { Odchylenie } \\
\text { standardowe }\end{array}$ \\
\hline Profesjonalne wykonywanie świadczeń medycznych & 4,7 & 0,6 \\
\hline
\end{tabular}




\begin{tabular}{|l|c|c|} 
przez pielęgniarki & & \\
\hline $\begin{array}{l}\text { Umiejętności manualne pielęgniarek podczas wykonywa- } \\
\text { nia czynności }\end{array}$ & 4,6 & 0,6 \\
\hline Uprzejmość i szacunek pielęgniarek wobec pacjentów & 4,5 & 0,6 \\
\hline $\begin{array}{l}\text { Reakcja personelu pielęgniarskiego na prośbę pacjenta o } \\
\text { udzielenie pomocy }\end{array}$ & 4,5 & 0,7 \\
\hline Skuteczność oferowanej pomocy pielęgniarskiej & 4,4 & 0,7 \\
\hline $\begin{array}{l}\text { Szanowanie godności i prywatności pacjenta przez perso- } \\
\text { nel pielęgniarski }\end{array}$ & 4,4 & 0,6 \\
\hline $\begin{array}{l}\text { Umożliwienie przez pielęgniarki pobytu rodziny lub } \\
\text { opiekuna przy chorym }\end{array}$ & 4,4 & 0,7 \\
\hline $\begin{array}{l}\text { Przestrzeganie zasad mycia rąk przed i po wykonaniu } \\
\text { czynności pielęgniarskich }\end{array}$ & 4,4 & 0,7 \\
\hline $\begin{array}{l}\text { Stosowanie rękawiczek jednorazowych podczas czynno- } \\
\text { ści pielęgniarskich }\end{array}$ & 4,3 & 0,8 \\
\hline $\begin{array}{l}\text { Czystość pomieszczeń i sprzętu medycznego w miejscu } \\
\text { pracy pielęgniarek }\end{array}$ & 4,3 & 0,7 \\
\hline $\begin{array}{l}\text { Ogólny poziom opieki pielęgniarskiej świadczonej w } \\
\text { Izbie Przyjęć }\end{array}$ & 4,2 & 0,5 \\
\hline $\begin{array}{l}\text { Zapewnienie przez pielęgniarki intymności podczas za- } \\
\text { biegów }\end{array}$ & 4,2 & 0,8 \\
\hline Dostępność personelu pielęgniarskiego & 4,2 & 0,7 \\
\hline $\begin{array}{l}\text { Gotowość personelu pielęgniarskiego do udzielania od- } \\
\text { powiedzi napytania }\end{array}$ & 4,1 & 0,8 \\
\hline Posiadana wiedza pielęgniarek na temat choroby pacjenta & 4,1 & 0,8 \\
\hline $\begin{array}{l}\text { Wzbudzanie zaufania i zapewnienie komfortu psychicz- } \\
\text { nego przez pielęgniarki }\end{array}$ & 4,0 & 0,8 \\
\hline $\begin{array}{l}\text { Ogólna ocena jakości opieki pielęgniarskiej realizowanej } \\
\text { w Izbie Przyjęć }\end{array}$ & 4,0 & 0,7 \\
\hline $\begin{array}{l}\text { Zrozumiałość i wyczerpujący charakter informacji otrzy- } \\
\text { manych od pielęgniarek }\end{array}$ & 3,9 & 0,8 \\
\hline Relacje pielęgniarek z pracownikami Izby Przyjęć & 3,7 & 0,9 \\
\hline $\begin{array}{l}\text { Współpraca między pielęgniarkami a pracownikami Izby } \\
\text { Przyjęć }\end{array}$ & 3,6 & 3,5 \\
\hline Zapoznanie przez pielęgniarki pacjenta z jego prawami & 0,9 \\
\hline
\end{tabular}

Źródło: opracowanie własne 
Powyższe zestawienie otrzymanych wyników zamieszczone w tabeli 1 przedstawia średnie wartości otrzymanych odpowiedzi w poszczególnych kategoriach. Pacjenci najwyżej ocenili profesjonalne wykonywanie świadczeń medycznych przez pielęgniarki $(x=4,7)$ oraz umiejętności manualne pielęgniarek podczas wykonywania czynności pielęgniarskich $(\mathrm{x}=4,6)$. Ponadto wysokie oceny otrzymała uprzejmość pielęgniarek i odnoszenie się z szacunkiem do pacjenta $(x=4,5)$ oraz reakcja personelu pielęgniarskiego na prośbę pacjenta o udzielenie pomocy $(\mathrm{x}=4,5)$.

Ankietowani najniżej ocenili zapoznanie przez pielęgniarki pacjenta $\mathrm{z}$ jego prawami $(\mathrm{x}=3,5)$ oraz współpracę między pielęgniarkami a pracownikami Izby Przyjęć $(x=3,6)$. Pacjenci nisko ocenili również relacje pielęgniarek z pracownikami Izby Przyjęć $(x=3,7)$ a także sposób przedstawiania informacji pacjentowi w sposób zrozumiały i wyczerpujący $(\mathrm{x}=3,9)$.

Dla ustalenia poziomu satysfakcji pacjentów z opieki pielęgniarskiej w Izbie Przyjęć uzyskaną możliwą ilość punktów podzielono na 4 grupy. Przedział całościowy możliwych do uzyskania punktów wynosił od 42 do 102, gdzie 42-55 punktów - ocena negatywna, 56-71 punktów - ocena dostateczna, 72-87 punktów - ocena dobra, 88-102 punktów - ocena bardzo dobra. Średnia ocena punktowa opieki pielęgniarskiej w Izbie Przyjęć wyniosła 83,9 punktów, co odpowiada ogólnej ocenie dobrej. Rycina 1 obrazuje rozkład poszczególnych kategorii ocen opieki pielęgniarskiej w opinii pacjentów przebywających w Izbie Przyjęć. 


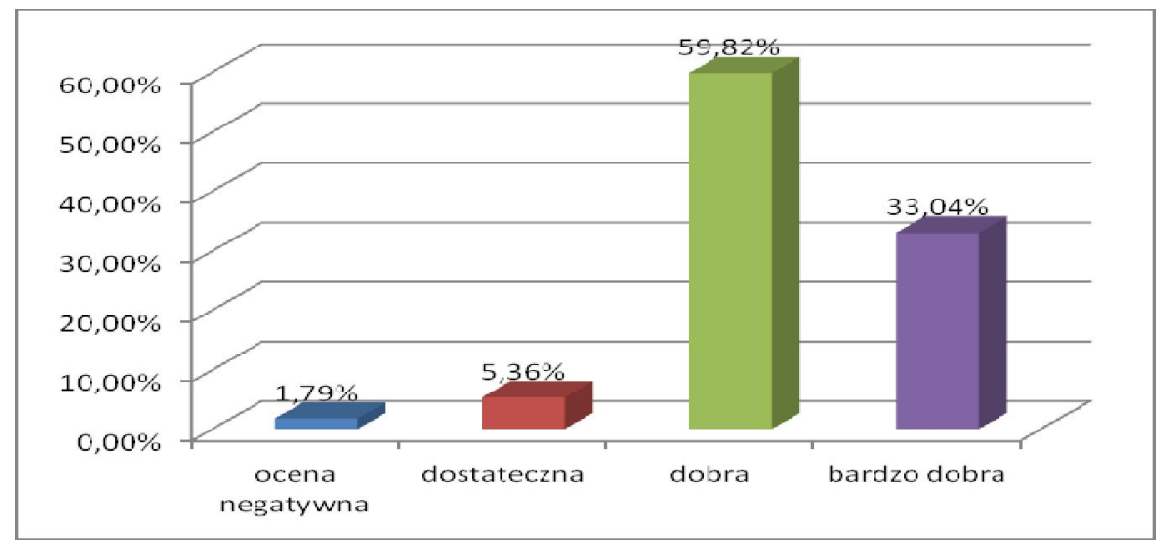

Rycina 1. Rozkład oceny ogólnej opieki pielęgniarskiej w opinii pacjentów Izby Przyjęć

Źródło: opracowanie własne.

Z przedstawionych danych na powyższej rycinie wynika, że ocena opieki pielęgniarskiej w Izbie Przyjęć w opinii 59,82\% pacjentów kształtuje się na poziomie dobrym. W dalszej kolejności jest to ocena bardzo dobra wyrażona przez 33,04\% respondentów. Tylko w niedużym zakresie jest to ocena dostateczna podana przez $5,36 \%$ badanych i ocena negatywna w opinii 1,79\% pacjentów.

\section{Satysfakcja pacjentów z poziomu opieki pielęgniarskiej w Izbie Przyjęć według korelacji zmiennych}

Analiza statystyczna nie wykazała istotnej zależności pomiędzy płcią ankietowanych, a oceną poziomu opieki pielęgniarskiej w Izbie Przyjęć ( $p=0,708$ ). 60,0\% kobiet oraz 59,5\% mężczyzn dobrze ocenia poziom opieki pielęgniarskiej w Izbie Przyjęć.

Wyniki badań pokazują, iż nie zaobserwowano istotnej statystycznie zależności pomiędzy wiekiem ankietowanych, a oceną poziomu opieki pielęgniarskiej w Izbie Przyjęć. 60\% osób w wieku 2150 lat oraz ponad 59\% osób w wieku 51-80 lat wykazuje dobrą ocenę poziomu opieki pielęgniarskiej w Izbie Przyjęć. Wiek nie wpływa na ocenę poziomu opieki $(\mathrm{p}=0,708)$. 
Analiza statystyczna nie wykazała istotnego związku pomiędzy stanem cywilnym ankietowanych, a ich oceną poziomu opieki pielęgniarskiej w Izbie Przyjęć. Ponad 52\% osób będących w związku oraz ponad 59\% respondentów w stanie wolnym ocenia dobrze poziom opieki pielęgniarskiej w Izbie Przyjęć. Stan cywilny nie jest istotnym czynnikiem jaki wpływa na ocenę poziomu opieki $(\mathrm{p}=0,18)$.

Analiza statystyczna wykazała istotną zależność pomiędzy wykształceniem ankietowanych, a ich oceną poziomu opieki pielęgniarskiej w Izbie Przyjęć. Spośród ankietowanych 13\% badanych deklarujących wykształcenie zawodowe lub podstawowe oceniła dostatecznie poziom opieki pielęgniarskiej na Izbie Przyjęć. Natomiast ponad $62 \%$ osób z wykształceniem średnim lub wyższym dobrze ocenia poziom opieki pielęgniarskiej w Izbie Przyjęć. Podczas analizy wyników zaobserwowano istotną zależność $(p=0,043)$, lecz o niskiej sile związku $(\mathrm{C}=0,26)$.

Badania statystyczne nie wykazały istotnej zależności pomiędzy miejscem zamieszkania ankietowanych, a ich oceną poziomu opieki pielęgniarskiej w Izbie Przyjęć. 63\% osób mieszkających w mieście oraz ponad $53 \%$ osób mieszkających na wsi oceniło dobrze poziom opieki pielęgniarskiej w Izbie Przyjęć. Miejsce zamieszkania nie jest istotnym czynnikiem wpływającym na ocenę opieki pielęgniarskiej $(\mathrm{p}=0,725)$.

Nie zaobserwowano istotnej statystycznie zależności pomiędzy trybem zgłoszenia się do Izby Przyjęć ankietowanych, a ich oceną poziomu opieki pielęgniarskiej w Izbie Przyjęć. Ponad 62\% osób zgłaszających się w trybie planowym oraz ponad 55\% osób zgłaszających się $\mathrm{w}$ trybie nagłym ocenia dobrze poziom opieki pielęgniarskiej w Izbie Przyjęć. Tryb zgłoszenia się do Izby Przyjęć nie jest czynnikiem mającym istotny wpływ na ocenę poziomu opieki pielęgniarskiej $(\mathrm{p}=0,506)$. 


\section{Satysfakcja pacjentów z jakości opieki pielęgniarskiej w Izbie Przyjęć według korelacji zmiennych}

Podczas analizy przeprowadzonych badań nie zaobserwowano istotnej statystycznie zależności pomiędzy płcią ankietowanych, a ich oceną jakości opieki pielęgniarskiej w Izbie Przyjęć $(p=0,156)$. Zdecydowana większość ankietowanych bez względu na płeć ocenia dobrze jakość opieki pielęgniarskiej realizowanej w Izbie Przyjęć

Badania dowiodły, że nie występuje istotna statystycznie zależność pomiędzy wiekiem ankietowanych, a ich oceną jakości opieki pielęgniarskiej w Izbie Przyjęć $(p=0,493)$. Zdecydowana ponad połowa ankietowanych bez względu na wiek dobrze ocenia jakość opieki pielęgniarskiej świadczonej w Izbie Przyjęć.

Badania statystyczne nie wykazały istotnej zależności pomiędzy stanem cywilnym ankietowanych, a ich oceną jakości opieki pielęgniarskiej w Izbie Przyjęć $(p=0,272)$. Ponad 58\% osób będących w związku oraz ponad $72 \%$ osób będących w stanie wolnym dobrze oceniła jakość opieki pielęgniarskiej pełnionej w Izbie Przyjęć.

Analiza statystyczna nie wykazała istotnej zależności pomiędzy wykształceniem ankietowanych, a ich oceną jakości opieki pielęgniarskiej w Izbie Przyjęć ( $p=0,449)$. Bez względu na wykształcenie ankietowani oceniali jakość opieki podobnie.

Nie zaobserwowano istotnej statystycznie zależności pomiędzy miejscem zamieszkania ankietowanych, a ich oceną jakości opieki pielęgniarskiej w Izbie Przyjęć ( $\mathrm{p}=0,916)$. Ponad 64\% osób mieszkających w mieście oraz ponad $61 \%$ osób mieszkających na wsi dobrze oceniła jakość opieki pielęgniarskiej w Izbie Przyjęć.

Analiza statystyczna nie wykazała istotnej zależności pomiędzy trybem zgłoszenia się do Izby Przyjęć ankietowanych, a ich oceną jakości opieki pielęgniarskiej w Izbie Przyjęć ( $\mathrm{p}=0,742)$. Ponad 65\% ankietowanych, którzy zgłosili się $\mathrm{w}$ trybie planowanym oraz ponad $60 \%$ osób, które zgłosiły się w trybie nagłym dobrze ocenia jakość opieki pielęgniarskiej w Izbie Przyjęć. 


\section{Dyskusja}

Badania własne zostały przeprowadzone w Izbie Przyjęć Samodzielnego Publicznego Zespołu Zakładów Opieki Zdrowotnej w Sierpcu. W badaniach uczestniczyło 112 respondentów w przedziale wiekowym od 21 roku życia do 80 lat. Ponad połowę ankietowanych osób stanowiły kobiety.

W toku badań własnych dokonano oceny satysfakcji pacjentów z opieki pielęgniarskiej realizowanej w Izbie Przyjęć. Zgromadzony materiał badawczy pozwolił ocenić poziom i jakość opieki pielęgniarskiej oraz wpływ wybranych czynników kształtujących powyższe parametry w opinii pacjentów przebywających w Izbie Przyjęć. Ankietowani pacjenci ocenili $\mathrm{w}$ przeważającej większości poziom i jakość świadczonej opieki w Izbie Przyjęć jako bardzo dobry i dobry. Pacjenci najwyżej ocenili profesjonalne wykonywanie świadczeń medycznych przez pielęgniarki, umiejętności manualne pielęgniarek podczas wykonywania czynności pielęgniarskich oraz uprzejmość i odnoszenie się z szacunkiem do pacjenta przez personel pielęgniarski a także reakcję personelu pielęgniarskiego na prośbę pacjenta o udzielenie pomocy. Najniżej natomiast, badani ocenili zapoznanie przez pielęgniarki pacjenta z jego prawami, przedstawienie informacji pacjentowi w sposób zrozumiały i wyczerpujący oraz współpracę i relacje między pielęgniarkami, a pracownikami Izby Przyjęć.

\section{Ocena poziomu opieki pielęgniarskiej realizowanej w Izbie Przy- jęć}

W wyniku badań własnych nie wykazano istotnej zależności pomiędzy płcią ankietowanych, a oceną poziomu opieki pielęgniarskiej w Izbie Przyjęć. Ponad 60,0\% kobiet oraz 59,5\% mężczyzn dobrze ocenia dobrze poziom opieki pielęgniarskiej realizowanej w Izbie Przyjęć. Podobnie jest także z zależnością w kategorii wieku ankietowanych. Otrzymane wyniki badań pokazują, iż nie zaobserwowano istotnej statystycznie zależności. 60\% osób w wieku 21-50 lat oraz ponad 59\% osób w wieku 51-80 lat dobrze oceniają poziom opieki 
pielęgniarskiej w Izbie Przyjęć. Jednoznacznie możemy stwierdzić, że wiek nie wpływu na ocenę poziomu opieki. Badania również nie wykazały istotnego statystycznego związku pomiędzy stanem cywilnym ankietowanych, a ich oceną poziomu opieki. Ponad 38\% osób będących w związku oraz ponad $22 \%$ respondentów w stanie wolnym ocenia bardzo dobrze poziom opieki pielęgniarskiej świadczonej w Izbie Przyjęć. Stan cywilny nie jest istotnym czynnikiem jaki wpływa na ocenę poziomu opieki. Badania statystyczne nie wykazały również istotnej zależności pomiędzy miejscem zamieszkania ankietowanych, a ich oceną poziomu opieki pielęgniarskiej. 63\% osób mieszkających w mieście oraz ponad 53\% osób mieszkających na wsi oceniła dobrze poziom opieki pielęgniarskiej. Natomiast analiza statystyczna wykazała istotną zależność pomiędzy wykształceniem ankietowanych, a ich oceną poziomu opieki pielęgniarskiej. Spośród ankietowanych $13 \%$ badanych deklarujących wykształcenie zawodowe lub podstawowe oceniła dostatecznie poziom opieki pielęgniarskiej na Izbie Przyjęć. Natomiast ponad $62 \%$ osób z wykształceniem średnim lub wyższym dobrze ocenia poziom opieki pielęgniarskiej w Izbie Przyjęć. Podczas analizy wyników zaobserwowano istotną zależność w tej kategorii lecz o niskiej sile związku C=0,26.

Nie zaobserwowano natomiast istotnej statystycznie zależności pomiędzy trybem zgłoszenia się do Izby Przyjęć ankietowanych, a ich oceną poziomu opieki pielęgniarskiej w Izbie Przyjęć. Ponad 62\% osób zgłaszających się w trybie planowym oraz ponad 55\% osób zgłaszających się $\mathrm{w}$ trybie nagłym ocenia dobrze poziom opieki pielęgniarskiej. Tryb zgłoszenia się do Izby Przyjęć nie jest czynnikiem mającym istotny wpływ na ocenę poziom opieki pielęgniarskiej.

Kozimala M. i Putowski L. przeprowadzili podobne badania na temat oceny poziomu satysfakcji pacjentów z opieki pielęgniarskiej w Centrum Opieki Medycznej w Jarosławcu w latach 2007-2008. Do badania przystąpiło 100 respondentów będących pacjentami. Badania potwierdziły brak istotnej zależności pomiędzy wiekiem ankietowanych, a ich oceną poziomu opieki pielęgniarskiej. Podobnie było 
w przypadku płci osób badanych. Po dokonaniu analizy okazało się, że płeć nie jest czynnikiem istotnym statystycznie wpływającym na ocenę poziomu opieki pielęgniarskiej. Również wykształcenie nie wykazało statystycznie istotnego wpływu na satysfakcję pacjentów [5].

\section{Ocena jakości opieki pielęgniarskiej realizowanej w Izbie Przyjęć}

Podczas analizy przeprowadzonych badań własnych nie zaobserwowano istotnej statystycznie zależności pomiędzy płcią ankietowanych, a ich oceną jakości opieki pielęgniarskiej na Izbie Przyjęć. Zdecydowana większość ankietowanych bez względu na płeć ocenia dobrze jakość opieki pielęgniarskiej. Badania dowiodły również, że nie występuje istotna statystycznie zależność pomiędzy wiekiem ankietowanych, a ich oceną jakości opieki Zdecydowana większość respondentów bez względu na wiek dobrze ocenia jakość opieki pielęgniarskiej w Izbie Przyjęć. Badania statystyczne nie wykazały także istotnej zależności pomiędzy stanem cywilnym ankietowanych, a ich oceną jakości opieki pielęgniarskiej. Ponad 58\% osób będących w związku oraz ponad $72 \%$ osób będących w stanie wolnym dobrze oceniła jakość opieki pielęgniarskiej. Ponadto analiza statystyczna nie wykazała istotnej zależności pomiędzy wykształceniem ankietowanych, a ich oceną jakości opieki pielęgniarskiej w Izbie Przyjęć. Bez względu na wykształcenie ankietowani odpowiadali podobnie. Po dokonaniu analizy wyników nie zaobserwowano również istotnej statystycznie zależności pomiędzy miejscem zamieszkania ankietowanych, a ich oceną jakości opieki pielęgniarskiej. Zdecydowana większość osób mieszkających w mieście - $64 \%$ oraz ponad $61 \%$ osób mieszkających na wsi dobrze oceniła jakość opieki pielęgniarskiej w Izbie Przyjęć. Analiza statystyczna nie wykazała także istotnej zależności pomiędzy trybem zgłoszenia się do Izby Przyjęć ankietowanych, a ich oceną jakości opieki pielęgniarskiej w Izbie Przyjęć. Ponad 65\% ankietowanych, którzy zgłosili się w trybie planowanym oraz ponad 60\% osób, 
które zgłosiły się w trybie nagłym dobrze ocenia jakość opieki pielęgniarskiej w Izbie Przyjęć.

Podobne badania przeprowadziła w ośrodku naukowym Juszczak K. Badaniu poddani byli pacjenci hospitalizowani w oddziałach zabiegowych takich jak oddział chirurgiczny, ortopedyczny i ginekologiczny. Grupa osób w wieku od 41 do 60 lat stanowiła najliczniejszą grupę respondentów. Analizując wiek respondentów nie stwierdzono istotnej zależności pomiędzy wiekiem, a oceną jakości opieki pielęgniarskiej. Również płeć nie miała wpływu istotnego statystycznie na ocenę jakości opieki pielęgniarskiej [6].

Jakość świadczonych usług udzielanych w zakładach opieki zdrowotnej jest jednym z najważniejszych wyzwań współczesnej ochrony zdrowia. Satysfakcja z opieki pielęgniarskiej jest kluczowym zagadnieniem, które powinno być monitorowane w sposób ciągły, przy użyciu odpowiednich narzędzi. Satysfakcja jest odpowiedzią pacjenta na proces opieki zdrowotnej. Niewątpliwie staje się ona istotnym kryterium oceny jakości opieki pielęgniarskiej. Systematyczne dokonywanie oceny opieki pielęgniarskiej staje się bodźcem do ciągłego doskonalenia systemu ochrony zdrowia.

\section{Wnioski}

1. Pacjenci w zdecydowanej większości ocenili opiekę pielęgniarską realizowaną w Izbie Przyjęć na poziomie dobrym $(59,82 \%)$ i bardzo dobrym (33,04\%). Tylko 5,36\% pacjentów ocenia opiekę dostatecznie i 1,79\% negatywnie.

2. Najwyżej pacjenci ocenili opiekę pielęgniarską realizowaną w Izbie Przyjęć w zakresie: profesjonalne wykonywanie świadczeń medycznych przez pielęgniarki, umiejętności manualne pielęgniarek podczas wykonywania czynności pielęgniarskich, uprzejmość pielęgniarek i odnoszenie się z szacunkiem do pacjenta oraz reakcje personelu pielęgniarskiego na prośbę pacjenta o udzielenie pomocy. 
3. Najniżej pacjenci ocenili opiekę pielęgniarską realizowaną w Izbie Przyjęć w zakresie: zapoznanie przez pielęgniarki pacjenta $\mathrm{z}$ jego prawami, współpraca między pielęgniarkami a pracownikami Izby Przyjęć, relacje pielęgniarek z pracownikami Izby Przyjęć, przedstawianie informacji pacjentowi w sposób zrozumiały i wyczerpujący.

4. Na ocenę poziomu opieki pielęgniarskiej w Izbie Przyjęć nie ma wpływu płeć, wiek, stan cywilny, miejsce zamieszkania oraz tryb zgłoszenia się pacjenta do szpitala. Natomiast posiadane wykształcenie pacjentów ma wpływ na ocenę poziomu opieki pielęgniarskiej w Izbie Przyjęć. Im wyższe wykształcenie respondentów tym wyższa ocena poziomu opieki pielęgniarskiej.

5. Na ocenę jakości opieki pielęgniarskiej w Izbie Przyjęć nie ma wpływu płeć, wiek, stan cywilny, miejsce zamieszkania, wykształcenie oraz tryb zgłoszenia się pacjenta do szpitala.

\section{Zalecenia dla praktyki pielęgniarskiej}

W opiece pielęgniarskiej realizowanej wobec pacjentów Izby Przyjęć należy utrzymać i kontynuować wysoki poziom świadczonej opieki. W podnoszeniu i doskonaleniu poziomu jakości opieki pielęgniarskiej i satysfakcji pacjenta z otrzymywanych świadczeń medycznych należy uwzględnić niskie wyniki ocen pacjentów w następujących kategoriach: zapoznanie przez pielęgniarki pacjenta z jego prawami, przedstawianie informacji pacjentowi w sposób zrozumiały i wyczerpujący, relacje i współpraca pielęgniarek z pracownikami Izby Przyjęć.

\section{Bibliografia / Bibliography:}

1. Garczyk D. Jakość i ocena opieki pielęgniarskiej. Neuroskop. 2012; 14:72-78.

2. Pędziwiatr A. Koncepcje teoretyczne dotyczące satysfakcji pacjenta. Pielęgniarstwo Polskie. 2005; 2(20):421-423. 
3. Sierpińska L., Dzirba A. Poziom satysfakcji pacjenta z opieki pielęgniarskiej na oddziałach zabiegowych. Pielęgniarstwo Chirurgiczne i Angiologiczne. 2011;1:18-22.

4. Detyna B., Detyna J. Jakość usług medycznych. Ocena statystyczna. Podstawy metodyczne. Wydawnictwo Difin. Warszawa 2011;90-99.

5. Kozimala M., Putowski L. Ocena satysfakcji pacjentów z opieki pielęgniarskiej w Centrum Opieki Medycznej w Jarosławcu. Annales Academiae Medicae Silesiensis. 2009;63(1):20-27.

6. Juszczak K. Juszczak K. Ocena jakości opieki pielęgniarskiej u chorych hospitalizowanych na oddziałach zabiegowych. Uniwersytet Medyczny im. Karola Marcinkowskiego w Poznaniu. Poznań 2012. 